\title{
Governance and Good Governance: A New Framework for Political Analysis
}

\author{
Yu Keping ${ }^{1}$
}

Received: 11 June 2017/ Accepted: 14 September 2017/Published online: 12 October 2017

(C) The Author(s) 2017. This article is an open access publication

\begin{abstract}
In a time of great change, accelerating globalization and increasing uncertainty, all countries, whether developed or developing, are searching for a new form of governance that is better adapted to the times so as to gain an advantage in economic competitiveness and create substantial and sustainable social growth. As governance theory is becoming the dominant political theory in response to the change, the values backing the discourse and texts consistent with them have helped revise the theory of government in mainstream politics and were agreed upon by global politicians, scholars, officials and entrepreneurs. When we comprehend governance theory based on the practice of public administration in China, it strikes us how theoretically and practically important governance theory is for rebuilding the intellectual system of China's democratic politics, searching for an institutional platform for good governance, transforming the public policy-making model and getting rid of the practice in public administration in the process of market-oriented development that is inefficient, or even fails in many ways.
\end{abstract}

Keywords Governance · Good governance · Governance reform · Public administration · Political science

The English word governance derives from Latin and ancient Greek and originally meant control, guidance and manipulation. Its meaning had long overlapped with the word government and was mainly used to refer to administrative and political activities related to national public affairs. However, in the 1990s, it was given a

This article is translated from a Chinese version, which was previously published in Nanjing Social Sciences, 9 (2001).

Yu Keping

yukp@pku.edu.cn

1 School of Government, Peking University, Beijing 100871, China 
new meaning by western political scientists and economists. Since then, the word has implied much more than it did traditionally and is starkly different from what the word government means. Instead of an exclusively English word, it is in common use among people speaking other major European languages; instead of an exclusively political term, it is widely used in social and economic spheres.

When trying to sum up what was happening in Africa in 1989, the World Bank used the term "crisis in governance" for the first time. Since then, governance as a word has been widely used in political development studies, especially for describing the political status of post-colonial and developing countries. By now, scholars from various countries have come up with five major propositions on governance as theory. They are as follows:

1. Governance refers to a set of institutions and actors that are drawn from but also beyond the Government. It challenges the authority of the State or the Government in the traditional sense and maintains that the Government is not the only power center of a state. As long as the power exercised by a public or private institution is recognized by the public, it is possible to become a power center at a specific level.

2. Governance identifies the blurring of boundaries and responsibilities for tackling social and economic issues. It indicates that, in modern society, the State is transferring its once exclusive responsibilities to civil society (i.e., private sector organizations and voluntary groups, which are undertaking more and more responsibilities that were formerly in the hands of the State). As a result, the boundaries between the State and society and between public and private sectors are becoming increasingly blurred, as are definitions of their responsibilities.

3. Governance identifies the power dependence involved in relationships between institutions involved in collective action. To be specific, every organization devoted to collective action has to depend on other organizations; to achieve its purpose, it has to exchange resources and negotiate a common goal with others, and the outcome of the exchange depends not only on the resources of each actor, but also on the rules of the game and the environment in which the exchange takes place.

4. Governance emphasizes the importance of autonomous self-governing networks of actors. A self-governing network as such has the authority to issue orders in a certain sphere and work with the Government in this sphere and share its responsibilities for public administration.

5. Governance recognizes the capacity to get things done without relying on the power of the Government to command or use its authority. In public affairs management, there are other management tools and techniques and the Government has the responsibility to use them to steer and guide public affairs (Stoker 1999).

Of all the definitions of governance, the one made by the Commission on Global Governance is one of the most representative and definitive. In a research report titled Our Global Neighborhood issued in 1995, the commission defined governance 
thus: "governance is the sum of the many ways individuals and institutions, public and private, manage their common affairs. It is a continuing process through which conflicting or diverse interests may be accommodated and cooperative action may be taken. It includes formal institutions and regimes empowered to enforce compliance, as well as informal arrangements that people and institutions either have agreed to or perceive to be in their interest." It has four features: governance is not a set of rules or an activity, but a process; the process of governance is not based on control, but on coordination; it involves both public and private sectors; it is not a formal institution, but continuing interaction. ${ }^{1}$

From the aforementioned definitions of governance, we can see that, essentially, governance means exercising authority to maintain order and meet the needs of the public within a certain range. The purpose of governance is to guide, steer and regulate citizens' activities through the power of different systems and relations so as to maximize the public interest. In terms of political science, governance refers to the process of political administration, including the normative foundation of political authority, approaches to dealing with political affairs and the management of public resources. It particularly focuses on the role of political authority in maintaining social order and the exercise of administrative power in a defined sphere.

Literally, there seems no great difference between "governance" and "government." Yet semantically, they are vastly different. To many scholars, a prerequisite for correct understanding of governance is to distinguish it from government. As Jean-Pierre Gaudin said, "Governance has to be distinguished from the traditional concept of government by the State from the very beginning" (Gaudin 1999). As a political administration process like government by the State, governance also requires authority and power and ultimately aims to maintain a normal social order. Despite their similarities, there are two fundamental differences between them.

First of all, the most fundamental, or even essential, difference between them is that governance requires authority but, unlike government, this authority does not necessarily come from organs of the Government. However, the authority for government is necessarily the State. The body of government is necessarily the public institutions in a society, while the body of governance can either be a public institution, a private one, or even a cooperation between the two. Governance is the cooperation between a political state and its civil society, the Government and nongovernmental organizations, public and private institutions, which can be mandatory or voluntary cooperation. It is mainly characterized by "contracting, rather than supervision; decentralization, rather than centralization; administration by the State, rather than redistribution by the State; management based on market principles, rather than management by administrative departments; cooperation between the State and private sectors, rather than being guided by the State" (Merrien 1999). Therefore, governance is a broader concept than government. From modern corporations to colleges and basic-level communities, all of them can do without

\footnotetext{
1 See Our Global Neighborhood compiled by Commission on Global Governance. Oxford: Oxford University Press, 1995, pp. 2-3.
} 
government by the State, but not without governance, if they are meant to run efficiently and in an orderly manner.

Second, power runs in different directions in management processes. For government by the State, power runs top-down all the time as it exercises the political authority of the Government to implement one-way management on social and public affairs by issuing orders and making and executing policies. By comparison, as an administrative process of interaction between the upper and lower levels, the body of governance manages public affairs through cooperation, negotiation, partnership, establishment of identity and common goals, etc. In essence, governance is cooperation based on market principles, common interest and identity. Its administrative mechanism does not rely on the authority of the Government substantially, but rather, the authority of a collaborative network. Its power is multi-directional and two-way, rather than unidirectional and top-down.

The immediate reason why Western political scientists and management scientists came up with the concept of governance and advocated replacing government is that they saw market failure, as well as state failure, in social resource allocation. Market failure means that it is impossible to bring about Pareto Optimum, a term in economics, by market-based means alone. As the market has innate limitations in restricting monopoly, supplying public goods, restraining extremely selfish behavior by individuals, bringing the anarchic state of production under control, cost accounting, etc., market-based means alone cannot bring about the optimum state of social resource allocation. Likewise, instruments of the State alone, including making plans and issuing orders, cannot do that either, or promote or safeguard the citizens' political and economic interests ultimately. In view of state and market failure, there has been a "growing fascination with using governance mechanisms as a solution to market failure and/or that in State coordination" (Jessop 1999).

Governance can compensate for certain deficiencies of the State and the market in regulation and coordination, but it is never a panacea. State and market can fail in social resource allocation; so can governance. So, a natural challenge facing scholars is how to overcome its failure and make it more effective. In response to the challenge, many scholars and international organizations have come up with a number of concepts, such as meta-governance, sound governance, effective governance and good governance. Among them, the most influential one is "good governance."

Ever since the State and government came into being, there had been the concept of good government in the English language. However, since the 1990s, good government, which had dominated as a political ideal, has been severely challenged around the world. The challenge to it comes from "good governance." Since the 1990s, there has been an increasing usage of the concept in English and Chinese political science literature, making it one of the most pervasive terms. What does good governance mean? What are the essential difference between good government and good governance? And what are the elements of good governance? Political scientists are still debating these questions.

In a nutshell, good governance refers to the public administration process that maximizes public interest. One of its essential features is that it is a kind of 
collaborative management of public life performed by both the State and the citizens and a new relationship between political State and civil society, as well as the optimum state of the two. To sum up all the perspectives on good governance, we can see that it has six essentials:

1. Legitimacy It refers to the state or quality that social order and authority are voluntarily recognized and obeyed. It has no direct relevance to laws and regulations, and from the legal angle something legal is not necessarily legitimate. Only the authority and orders genuinely recognized by people within a specific group are legitimate in political science. The higher the degree of legitimacy is, the higher the level of good governance will be. The principal approach to achieving and improving legitimacy is to maximize the consensus and political identity shared by citizens. Therefore, good governance requires the relevant administrative bodies and administrators to manage various conflicts of interest among citizens and between them and the State to the maximum so as to obtain the citizens' maximum consent to and approval of their public administration activities.

2. Transparency It refers to the publicity of political information. All citizens are entitled to the information on State policies that are related to their own interests, including legislative activities, policy-making, legal provisions, policy enforcement, administrative budget, public expenditure and other relevant political information. Transparency requires that the aforementioned political information be duly communicated to citizens through various media vehicles so that they can participate in public policy-making and supervise the process of public administration in an effective manner. The higher the degree of transparency is, the higher the level of good governance will be.

3. Accountability Accountability means holding every person accountable for his or her own behavior. In public administration, it refers in particular to the duties related to a certain position or institution and its corresponding obligations. Accountability means that administrators and administrative bodies must fulfill the functions and obligations of the positions they hold. If they fail to fulfill their bounden functions or duties, or if they do so in an inappropriate manner, their conduct constitutes dereliction of duty or lack of accountability. The more accountability the public, especially public officers and administrative bodies have, the higher the level of good governance will be. In this regard, good governance requires the employment of both law and ethics to enhance the accountability of individuals and institutions.

4. Rule of law Essentially, rule of law means that law is the supreme principle in public political administration that should be observed by all government officials and citizens, who should be all equal before the law. The immediate goal of rule of law is to regulate citizens' behavior, manage social affairs and maintain a normal order in social life, while its ultimate goal is to protect citizens' basic political rights, including freedom and equality. In this sense, rule of law is opposite to rule of man as it both regulates citizens' behavior and restricts the conduct of the State. It is the arch-enemy of political autocracy. Rule of law is a basic requirement of good governance, which would be 
impossible without a sound legal system, due respect for the law or a social order based on the law.

5. Responsiveness Responsiveness is closely associated with the aforementioned concept of accountability. In a sense, it is an extension of accountability. Essentially, it means that public administrators and administrative bodies must respond to the demands of citizens in a timely and responsible manner, and that it is forbidden to make delays without cause or leave any issue unresolved without response. When necessary, they should proactively solicit advice from citizens, explain their policies to them and answer their questions on a regular basis. The greater the level of responsiveness is, the higher the level of good governance will be.

6. Effectiveness It mainly refers to management efficiency. It has two essential meanings: rational administrative structure, scientifically designed administrative procedures and flexible administrative activities; and minimized administrative costs. Ineffective or inefficient administrative activities are out of tune with good governance. The higher the level of good governance is, the higher the effectiveness of administration will be.

Good governance is the active and productive cooperation between the State and citizens, and the key to its success lies in the powers participating in political administration. Only when citizens have sufficient political power to participate in elections, policy-making, administration and supervision can they prompt the State and join hands with it to build public authority and order. Apparently, democracy is the only practical mechanism that can safeguard the fully free and equal political power owned by citizens. Hence, good governance is organically combined with democracy. In an autocratic system, it is possible to have good government when the system is at its best, but it is impossible to have good governance. Good governance can only be achieved in a free and democratic political system, as it cannot emerge without freedom and democracy.

In fact, there were more profound causes why the theory and practice of good governance sprang up in the 1990s. First of all, good governance is more widely applicable than good government in the traditional sense. Good government has the same scope of coverage as the State. In modern society, the State cannot interfere in many areas, from civil organizations like companies, communities, clubs and professional associations to the international community. In contrast, good governance is not subject to the scope of coverage of the State as it is also indispensable to companies, communities, regions, states and the international community. Second, globalization is becoming the dominant feature of our time, which, in fact, has been referred to by many as the "Global Age." One important feature of globalization is the growing influence of transnational organizations and supranational organizations and the diminishing sovereignty of nation-states and diminishing power of their governments. As the government authority of nationstates in the traditional sense is eroded, good governance is playing an increasingly important role. It is because the international community and the society within a state are still in want of public authority and order, a new kind of public authority and order that can only be achieved through good governance, rather than created by 
the State in the traditional sense. Finally, good governance is an inevitable consequence of democratization. Democratization is a political feature of our time, as well as an irresistible historical trend. One of its essential significances is that political power is returning from political states to civil societies. Limited government power and the shrinking functions and powers of the State do not necessarily mean vanishing social and public authority, but rather that public authority will be based more on cooperation between the State and citizens.

Immature and essentially ambiguous as it is, governance theory is a breakaway from the traditional dichotomous thinking that has long been dominant in social sciences, i.e., market versus planning, public sector versus private sector, political State versus civil society and nation-state versus international community. It regards effective administration as cooperation between the two; it tries to develop completely new techniques for public affairs management; it emphasizes that administration is cooperation; it argues that legitimate power comes not only from the State, but also from the civil society. The theory also deems governance to be a new practical form of modern democracy. Those are all its contributions of positive significance to political studies. However, there is also a dangerous tendency in Western countries to use the theory to justify some transnationals' and superpowers' interference with the internal affairs of other countries and pursuit of international hegemony. Based on the premise that the role of the State and state sovereignty are insignificant and the boundaries of nation-states are blurred, governance theory, especially global governance theory, emphasizes the nature of governance as a transnational and global activity. The danger here is that undermining the important roles of state sovereignty and sovereign government in domestic and international governance might be regarded as a theoretical basis for the superpowers and multinationals to interfere with the internal affairs of other countries and promote their international hegemonic policies. Therefore, we must keep a wary eye on the dangerous tendency of governance theory, especially global governance theory.

Open Access This article is distributed under the terms of the Creative Commons Attribution 4.0 International License (http://creativecommons.org/licenses/by/4.0/), which permits unrestricted use, distribution, and reproduction in any medium, provided you give appropriate credit to the original author(s) and the source, provide a link to the Creative Commons license, and indicate if changes were made.

\section{References}

Commission on Global Governance (ed.). 1995. Our global neighborhood, 2-3. Oxford: Oxford University Press.

Gaudin, Jean-Pierre. 1999. Modern governance, yesterday and today: Some clarifications to be gained from French government policies. International Social Science Journal 50: 47-56. (Chinese edition).

Jessop, Bob. 1999. The rise of governance and the risks of failure: The case of economic development. International Social Science Journal 50: 29-45. (Chinese edition).

Merrien, Francois-Xavier. 1999. Governance and modern welfare states. International Social Science Journal 50: 57-67. (Chinese edition).

Stoker, Gerry. 1999. Governance as theory: Five propositions. International Social Science Journal 50: 17-28. (Chinese edition). 
Yu Keping is University Chair Professor, Dean of School of Government and the Director of the Center for Chinese Politics at Peking University. He is a noted scholar and is the author of many well-received books including the widely praised Democracy is a Good Thing. In addition to his academic work, he had served as the Vice President of Central Bureau of Compilation and Translation under the Central Committee of CPC for many years. 